\title{
軸力と曲げを受ける円形鋼管の局部座屈挙動解析に関する研究 ELASTO-PLASTIC ANALYSIS FOR LOCAL BUCKLING BEHAVIOR OF CIRCULAR TUBES SUBJECTED TO COMPRESSION AND BENDING
}

\author{
安井信行* \\ Nobuyuki YASUI
}

\begin{abstract}
This paper presents the method to analyze the local buckling behavior of circular tubes subjected to compression and bending. The analytical method proposed here is mainly based on the technique used in Ref.21). However, the present analysis takes into account effects of asymmetrical local buckling, and effects of both kinematic and isotropic strain hardening. The numerical results are compared with the results of experiments. According to the method proposed here, the numerical results can well predict the load-deflection curves under monotonic loading and the gradually deteriorating behavior under cyclic loading.
\end{abstract}

\section{Keywords : elasto-plastic analysis, cyclic loading, circular tube, local buckling} 弾塑性解析，繰返し載荷，円形鋼管，局部座屈

1. 序

多層骨組が地震による繰返し水平力を受ける時,その柱材には軸力 と繰返し曲げが同時に作用し, 一般に軸力は変動する.下層部の柱材 の弾塑性挙動は骨組全体の応答に重要な影響を与えるため, その繰返 し挙動を明らかにすることは骨組の耐震性能を評価する上で重要な課 題である。

板要素や鋼管で構成される鋼構造骨組の柱材は, 幅厚比や径厚比の 大きさによっては局部座屈が生じ, 耐力を決定づける要因となる。そ のため, 局部座屈を生じる柱材の挙動を明らかにすべく, 劣化挙動を 表現可能な解析が数多く行われてきた.

三谷ら ${ }^{1,2}$ は， $\mathrm{H}$ 形鋼柱の局部座屈を塑性関節線による崩壊機構で 表現し,エネルギー散逸率最大の原理と仮想仕事式を用いて局部座屈 後の荷重一変形挙動を求め, 実験結果と比較している. 松井ら ${ }^{3)}$ は, $\mathrm{H}$ 形鋼柱に局部座屈が生じる骨組の挙動を, 実験結果を基にした柱の モーメントと回転角の関係を塑性ヒンジに導入することによって解析 している. 大井ら 4 6)は, 複数の履歴バネからなる弾塑性ジョイント. を部材端に配置し, 局部座屈による劣化型の復元力特性を履歴バネに 与えて解析を行い, 実験結果を良好に再現している.内田ら7〜10)は, 軸力と繰返し曲げを受ける角形鎆管柱を対象に, 劣化型の復元力特性 を与えた 1 次宇有限要素モデルと離散化要素モデルを用いた解析を
行っており，軸昰の収束と発散について考察している．また，山田ら は, $\mathrm{H}$ 形鋼柱と角形鋼管柱を対象に，短柱圧縮試験の結果を統計処理 し，数值積分による面内解析法を局部座屈による劣化域にまで発展さ せ ${ }^{11,12)}$, 多層骨組の弾塑性応答解析を行っている ${ }^{13)}$. 上場ら ${ }^{14,15) は, ~}$ 3次元弾塑性有限要素解析プログラムを用いて円形鋼管柱の局部座屈 挙動を解析している。

汎用の 3 次元有限要素解析は, 局部座屈の詳細な検討が可能である が,骨組に導入して解析することは未だ困難である。また，崩壊機構 に仮想仕事式を用いる手法1,2,16)では，繰返し載荷に対する崩䏅機構 の成立条件が見い出しにくく,連続的な繰返し挙動を解析的に表現す るには至っていない. 一方, 局部座屈が発生する部位に耐力劣化の履 歴則を導入する方法は, 実現象を直接モデル化しているため数值計算 の簡便さがあり，実現象を説明し易い利点がある ${ }^{17)}$.そのため, 履歴 則をモデル化する方法は地震応答解析にも用いられ $13,18,19)$, 桑村ら 20$)$ は,履歴モデルの精度が耐震性能の評価誤差に及ほす影響を考察して いる.これらの研究に用いられた履歴モデルは実験結果をもとに与え られるため, 部材の断面寸法が異なる場合や軸力比が変化する場合に は，個別に実験を行って履歴モデルを作成する必要がある．

著者は文献 21)において, 素材の応力度一歪度関係のみ与えられれ ば,圧縮引張の繰返し軸力を受ける円形鋼管の局部座屈挙動を表現可

本諭文の一部は日本建築学会大会学術講演梗概集, C-1, 構造III, 2001.9に発表している。

* 長崎総合科学大学工学部建築学科 助手. 工修 $\quad$ Research Assoc., Dept. of Architecture, Faculty of Engineering, Nagasaki Institute of Applied Science, M. Eng. 
能な解析モデルを提案した。この解析モデルは, 局部座屈が発生する 領域に弾塑性ヒンジによる崩壊機構を用いることにより,弾塑性の連 続的な繰返し劣化挙動を表現可能としている.

本論では,この解析モデルを拡張し, 変動軸力と繰返し曲げを受け る円形鎆管の局部座屈挙動に適用する.解析結果は軸力と繰返し曲げ を受ける円形鋼管の実験結果と比較する.

\section{2. 解析方法}

\section{1 解析モデルおよび基本仮定}

本論で仮定する解析モデルを図 1 に示す. 解析モデルは全長 $l_{T}$ の円 形鍓管の両端に, 長さ $2 l$ の局部座屈域（以後, 単に座屈域と称す）を 配置したものである.局部座屈が発生しない中央部分は弾性の曲げせ ん断棒でモデル化する。座屈域は円形鋼管断面を $n_{d}$ 個に等分割し，そ の分割断面と断面積が等価な弾塑性直線材と弾塑性ヒンジ (以後, 直 線材, ヒンジと称す) で構成される ${ }^{21)}$ 。ここで, 軸方向に直列配置さ れた 2 本の直線材と 4 つのヒンジをあわせて座屈モデルと称す．図 2 には座屈域の変形と, 材端力, 材端変位を示す. 局部座屈は, 座屈域 の各座屈モデルが半径方向（図2の $r_{\varphi}$ 方向）に変形することによって 表現する，座屈域の両端面では平面保持を仮定し，座屈モデルの材端 側節点は,端面に対する境界条件を固定とすることによって鋼管中心 に対する変位を生じない. 一方, 材中央側節点は弾性の曲げせん断棒 と慗がるが，図3に示すように，各節点位置には座屈しない弾塑性の 円形鋼管分割断面があるものと見なし，その位置の応力に応じて分割 断面の円周方向応力が 0 となるように半径方向に移動させる.すなわ ち, 軸方向に圧縮力を受ける材中央側節点はポアソン比により鋼管の 外側に移動し，軸方向に引張力を受ける節点は鋼管の内側に移動す る.これは軸圧縮力のみ作用寸る文献 21)の境界条件と同じである.

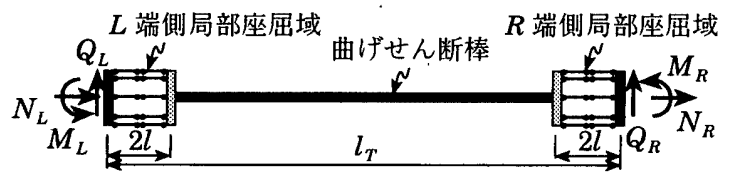

図 1 解析モデル

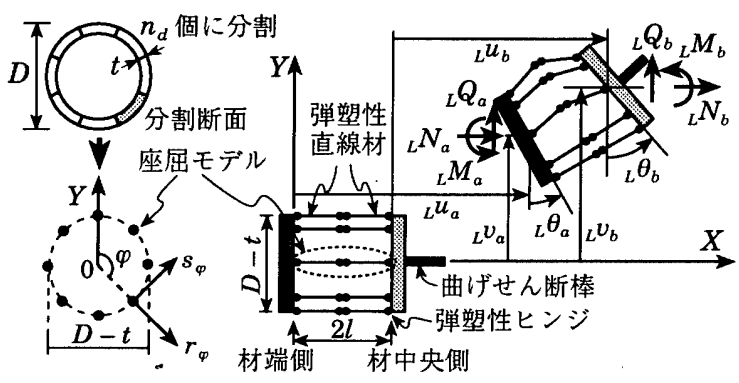

図 $2 L$ 端側座屈域の材端力と材端変形

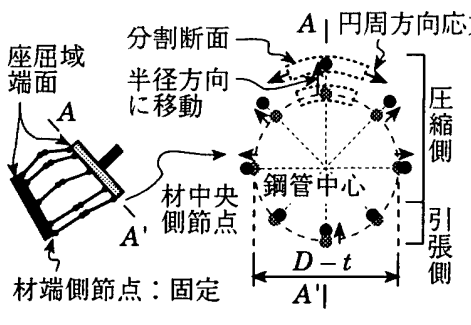

図 3 材中央側節点の半径方向への移動

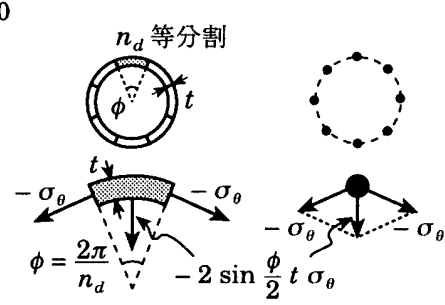

図 4 円周方向応力の半径方向成分
座屈モデルが円形鋼管の外側に膨らむか内側にへこむかは,材端側 節点付近の円周方向応力によって決定される.半径方向の移動が拘束 された材端側節点付近では, 軸方向に圧縮力が作用するとポアソン比 により圧縮の円周方向応力が発生する. 一方, 軸方向に引張力が作用 する場合には円周方向応力は引張となる．図4に示すように，座屈域 に発生する円周方向応力 $\sigma_{\theta}$ (圧縮を正) が $n_{d}$ 個の分割断面内で一様 であるとすれば,その合力として半径方向力を座屈モデルに作用させ ることができる. 図5に半径方向力の分布と座屈モデルの半径方向変 形の概略を示す，軸方向に圧縮力が作用する場合（図 $5 a$ )，材端側節 点付近の半径方向力は鋼管中心から外向きに作用するため座屈モデル は外側に膨らみ，いわゆるP- $\Delta$ 効果によって局部座屈が成長する。一 方, 軸方向に引張力が作用する場合には（図 $5 b$ )，材端側節点付近の 半径方向力は内向きに作用し，座屈モデルがへこむ原因となる．した がって,座屈モデルが鋼管の外側に膨らむか内側にへこむかの区別は 材端側節点が半径方向に拘束されることが前提条件となり，材端側節 点が拘束されない場合は座屈モデルが变形する方向を区別できない.

本解析モデルでは，図5に示す座屈域に連続的に分布する半径方向 力は， $n_{q}$ 個の集中荷重として座屈モデルに作用させる.

本解析モデルに用いる基本仮定は，以下のと抢りである。

1）座屈域は平面応力場とする。

2）材料は von Mises の降伏条件に従う.

3）応力度と歪度の関係は Ramberg-Osgood 型とする。

4）歪硬化は移動硬化と等方硬化の組合せとし，移動硬化は Pragerの移動硬化則に従う.

5）弾塑性ヒンジの歪硬化特性はShanley ${ }^{22)}$ の理論より得られる関 係21)を適用する。

2.2 座屈域と座屈モデルの材端力および材端変位の関係

図 2 に示す $L$ 端側座屈域の全体座標系 $X-Y$ における材端力 $\left.{ }_{L} \boldsymbol{P}\right\}$ と 材端変位 $\left.{ }_{L} \boldsymbol{d}\right\rangle$ を次式で定義する。

$$
\begin{aligned}
& \left\{{ }_{L} \boldsymbol{P}\right\}=\left\{\begin{array}{llllll}
{ }_{L} N_{a} & { }_{L} Q_{a} & { }_{L} M_{a} & { }_{L} N_{b} & { }_{L} Q_{b} & { }_{L} M_{b}
\end{array}\right\}^{T} \\
& \left\{{ }_{L} d\right\}=\left\{\begin{array}{lllllll}
{ }_{L} u_{a} & { }_{L} v_{a} & { }_{L} \theta_{a} & { }_{L} u_{b} & { }_{L} v_{b} & { }_{L} \theta_{b}
\end{array}\right\}^{T}
\end{aligned}
$$

ここで, $N, Q, M$, および $u, v, \theta$ はそれぞれ座屈域端部の軸力, 剪 断力, モーメント, および $X$ 方向変位, $Y$ 方向変位, 回転角である. 左下添字 $L$ は円形鋼管の $L$ 端側であることを，右下添字 $a$ または $b$ は 座屈域の $a$ 端側(材端側)または $b$ 端側(材中央側)であることを示す.

図 2 に示す $Y$ 軸から角度 $\varphi$ の位置にある座屈モデルのヒンジは, $X$ $-r_{\varphi}$ 面内, 寸なわち円形鋼管の半径方向にのみ座屈モデルが変形す るよう回転し，その変形と材端力を図6(a)に示す．また，座屈モデル は $X-s_{\varphi}$ 面内, すなわち図6(b)に示す円周方向には面内せん断変形 のみ生じるものとする，座屈域と同様に，図6に示す座屈モデルにつ いても，材端力と材端変位を次式で定義する。

$$
\begin{aligned}
& \left\{{ }_{L} \boldsymbol{P}_{\varphi G}\right\rangle=\left\{{ }_{L} N_{\varphi G a}{ }_{L} \boldsymbol{Q}_{\varphi G a}{ }_{L} M_{\varphi G a}{ }_{L} N_{\varphi G b}{ }_{L} \boldsymbol{Q}_{\varphi G b}{ }_{L} M_{\varphi G b}{ }_{L} \boldsymbol{Q}_{s \varphi G}\right\}^{T} \\
& \left\{{ }_{L} \boldsymbol{d}_{\varphi G}\right\}=\left\{\begin{array}{lllllll}
{ }_{L} u_{\varphi G a} & { }_{L} v_{\varphi G a} & { }_{L} \theta_{\varphi G a} & { }_{L} u_{\varphi G b} & { }_{L} v_{\varphi G b} & { }_{L} \theta_{\varphi G b} & { }_{L} \gamma_{\varphi G}
\end{array}\right\}^{T}
\end{aligned}
$$

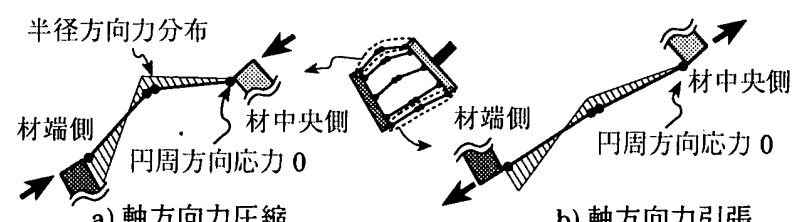

b) 軸方向力引張

図 5 座屈モデルの半径方向変形と半径方向力 
各記号の右下添字 $\varphi$ は, $Y$ 軸から角度 $\varphi$ の位置にある座屈モデルであ ることを，Gは全体座標系であることを示している. 円周方向の面内 せん断力 ${ }_{L} \boldsymbol{Q}_{s \varphi G}$ は座屈モデルの全長に渡って一定であると仮定し，面 内せん断変形 ${ }_{L} \gamma_{\phi G}$ は図 6(b)の材端変形を用いて次式で表される.

$$
\begin{aligned}
& { }_{L} Q_{s \varphi G} l={ }_{L} M_{s \varphi G a}={ }_{L} M_{s \varphi G b} \\
& { }_{L} \gamma_{\phi G}=\left({ }_{L} v_{s \varphi G a}-{ }_{L} v_{s \varphi G b}\right)+l\left({ }_{L} \theta_{s \varphi G a}+{ }_{L} \theta_{s \varphi G b}\right)
\end{aligned}
$$

以上の定義より，座屈域と座屈モデルの材端力, 材端変形には, 幾 何学的変形により以下の関係が成立する.

$$
\begin{aligned}
& \left.\left\langle{ }_{L} \boldsymbol{d}_{\varphi G}\right\}={ }_{L} C\right]\left\langle{ }_{L} \boldsymbol{d}\right\rangle \\
& \left\langle{ }_{L} \boldsymbol{P}\right\}=\sum^{n_{d}}\left[{ }_{L} C\right]^{T}\left\{{ }_{L} \boldsymbol{P}_{\varphi G}\right\}
\end{aligned}
$$

ここで, $R=(D-t) / 2$ として $\left.{ }_{L} C\right]$ は次式で表される。

$$
\left.{ }_{L} C\right]=\left[\begin{array}{cccccc}
1 & 0 & -R \cos \varphi & 0 & 0 & 0 \\
0 & \cos \varphi & 0 & 0 & 0 & 0 \\
0 & 0 & \cos \varphi & 0 & 0 & 0 \\
0 & 0 & 0 & 1 & 0 & -R \cos \varphi \\
0 & 0 & 0 & 0 & \cos \varphi & 0 \\
0 & 0 & 0 & 0 & 0 & \cos \varphi \\
0 & \sin \varphi & l \sin \varphi & 0 & -\sin \varphi & l \sin \varphi
\end{array}\right]
$$

\section{3 座屈モデルの材端力増分と材端変位增分の関係}

\subsection{1座屈モデルの部材座標}

図7(a)には $L$ 端側座屈域における座屈モデルの部材座標系 $x_{m}-r_{m}$ に作用する材端力と材端变形を示す. $x_{m}$ 軸は円形鋼管中心位置から $(D-t) / 2$ だけ離れた位置であり， $r_{m}$ 軸は $x_{m}$ 軸と直交するよう半径 方向に設定する。したがって, 固定端である材端側節点 $A$ は円周方向 歪度が 0 となり, 節点 $B$ はその位置での円周方向応力度が 0 となる.よ う $r_{m}$ 方向に変位 $\boldsymbol{y}$ を生じる.

図 7(b)には半径方向に作用する材端力と集中荷重を示す。1本の直 線材を $n_{q}$ 個に等分割した長さ $l_{\alpha}$ の領域では円周方向応力度 $\sigma_{\theta}$ が一様 に作用するとし, 図 4 に示す $\sigma_{\theta}$ の半径方向力を集中荷重 $q_{a k}, q_{b k}$ とし て各領域の中心位置に作用させる. $l_{\beta a k}, l_{\beta b k}$ は各弾塑性直線材の節点 $\mathrm{A}, \mathrm{C}$ 側からそれぞれ $q_{a k}, q_{b k}$ が作用する位置までの距離である。

\subsection{2 弾塑性ヒンジの歪硬化特性}

本解析で用いる弾塑性ヒンジは，図8に示す $n_{t}$ 組の理想サンドイッ チ断面とする. 図 8 の長さ $l_{0}$ の片持ち柱の軸力增分 $d N$ とモーメント 増分 $d M$ の関係は, ヒンジ回転角増分 $d \theta$ 用いて次式で表される ${ }^{21)}$.

$$
d M=\frac{\sum_{i=1}^{n_{t}} t_{i}\left(E_{i t 1}-E_{i t 2}\right)}{2 \sum_{i=1}^{n_{t}}\left(E_{i t 1}+E_{i t 2}\right)} d N+\frac{\pi^{2} N_{y} \sum_{i=1}^{n_{t}} t_{i}^{2}}{16 l_{0} \sigma_{Y} n_{t}} E_{R} d \theta
$$

ここで, $E_{R}$ は等価係数（換算係数）であり，次式で表される.

$$
E_{R}=\frac{1}{2 \sum_{i=1}^{n_{t}} t_{i}^{2}}\left\{\sum_{i=1}^{n_{t}} t_{i}^{2}\left(E_{i t 1}+E_{i t 2}\right)-\frac{\left[\sum_{i=1}^{n_{t}} t_{i}\left(E_{i t 1}-E_{i t 2}\right)\right]^{2}}{\sum_{i=1}^{n_{t}}\left(E_{i t 1}+E_{i t 2}\right)}\right\}
$$

$E_{i t 1}, E_{i t 2}$ は図 8 に示す $i$ 番目理想サンドイッチ断面の接線係数, $t_{i}$ は その集中断面間距離であり， $N_{y}$ および $\sigma_{Y}$ はそれぞれ降伏軸力および 降伏応力度である.(9)式の関係を図 7(b)の各弾塑性ヒンジに適用す ると, 弾塑性ヒンジの歪硬化特性を与える 4 つ式が得られる。ここ で, $(9)$ 式中の $l_{0}$ は局部座屈の曲げ変形を弾塑性ヒンジに集約する長 さであるが，解析が安定するよう $l_{0}$ は常にl/ 2 を代入する.

\subsection{3 円周方向の忍力と歪}

基本仮定 2)，4)より，von Mises の降伏条件に歪硬化として等方硬 化則と Pragerの移動硬化則を適用すれば, 弾塑性の応力度増分と歪 度增分の関係 ${ }^{23)}$ が得られる.この応力度と歪度の関係に対して基本仮 定 1)を適用すれば, 軸方向応力度 $\sigma_{x}$, 円周方向応力度 $\sigma_{\theta}$, および剪 断応力度 $\tau_{x \theta}$ からなる平面応力場を, 軸方向歪度 $\varepsilon_{x}$, 円周方向歪度 $\varepsilon_{\theta}$, および剪断歪度 $\varepsilon_{x \theta}$ を用いて表現できる。

節点 $A C$ 間および節点 $B C$ 間の円周方向歪度増分 $d \varepsilon_{\theta a k}, d \varepsilon_{\theta a k}$ は, 圧 縮を正として次式で表される。

$$
\begin{aligned}
& d \varepsilon_{\theta a k}=-\frac{2}{D-t} l_{\beta a k}\left(d \theta_{m a}+d \theta_{a c}\right) \\
& d \varepsilon_{\theta b k}=-\frac{2}{D-t}\left\{\left(l-l_{\beta b k}\right)\left(d \theta_{b c}-d \theta_{m b}\right)+d y\right\}
\end{aligned}
$$

ここで, $d \theta_{m a}, d \theta_{m b}$ は材端回転角增分, $d \theta_{a c}, d \theta_{b c}$ はヒンジ回転角増 分であり, $d y$ は節点 $B$ の半径方向変位增分である. なお, $d y$ は節点 $B$ 位置での円周方向歪度増分 $d \varepsilon_{\theta B}$ と以下の関係がある.

$$
d y=-\frac{D-t}{2} d \varepsilon_{\theta B}
$$

$d \varepsilon_{\theta B}$ は, 平面応力場の応力度一歪度関係において円周方向応力度を 0 とすることにより, 軸方向応力度増分 $d \sigma_{x}$ と剪断応力度増分 $d \tau_{x \theta B}$ を 用いて表現可能となる。

面内剪断力が座屈モデルの全長に渡って一定であるため, 剪断応力 度增分 $d \tau_{x \theta a k}, d \tau_{x \theta b k}$ と剪断歪度增分 $d \varepsilon_{x \theta a k}, d \varepsilon_{x \theta b k}$ は, 図 9 に示寸部 材座標系の剪断力増分 $d Q_{s m}$, 剪断変形増分 $d \gamma_{m}$ と以下の関係がある.

$$
\begin{aligned}
& d \tau_{x \theta a k}=d \tau_{x \theta b k}=\frac{\sigma_{Y}}{N_{y}} d Q_{s m} \\
& d \gamma_{m}=l_{a}\left\{\sum_{k=1}^{n_{q}} d \varepsilon_{x \theta a k}+\sum_{k=1}^{n_{q}} d \varepsilon_{x \theta b k}\right\}
\end{aligned}
$$

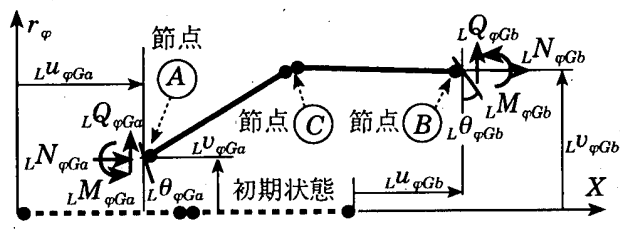

図 6(a) 座屈モデルの半径方向材端力と材端変形

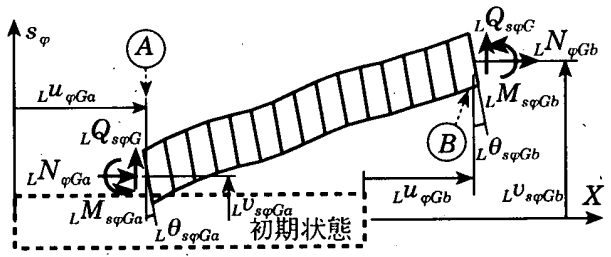

図 6(b) 座屈モデルの円周方向材端力と材端変形

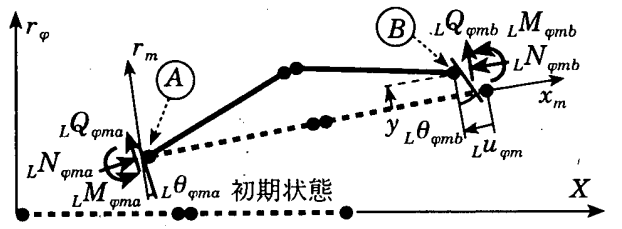

図7(a) 部材座標系における 座屈モデルの材端力と材端変形

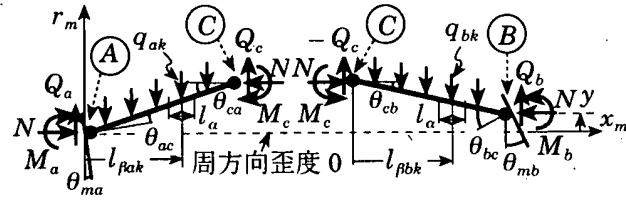

図 7(b) 座屈モデルの力の釣合

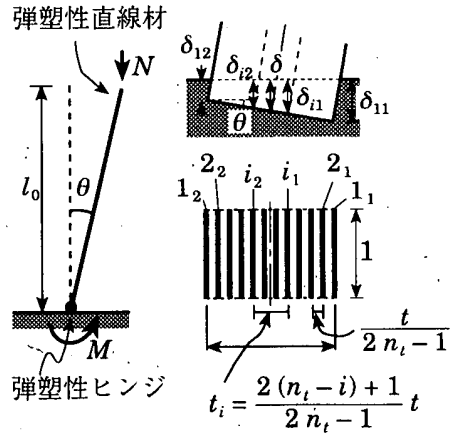

図 8：片持ち柱と弾塑性ヒンジ 


\subsection{4 釣合式}

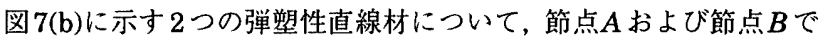
の半径方向に作用するモーメントの釣合より次式を得る.

$$
\begin{gathered}
-d M_{a}-d M_{c}+l N\left(d \theta_{m a}+d \theta_{a c}\right)+l\left(\theta_{m a}+\theta_{a c}\right) d N \\
+l d Q_{c}-\sum_{k=1}^{n_{q}}\left(l_{\beta a k} d q_{a k}\right)=0 \\
d M_{c}+d M_{b}-l N\left(d \theta_{b c}-d \theta_{m b}\right)-l\left(\theta_{b c}-\theta_{m b}\right) d N \\
+l d Q_{c}+\sum_{k=1}^{n_{q}}\left\{\left(l-l_{\beta b k}\right) d q_{b k}\right\}=0
\end{gathered}
$$

ここで, 半径方向の集中荷重増分 $d q_{a k}, d q_{b k}$ は, 次式で表される.

$$
d q_{a k}=-2 \sin \frac{\phi}{2} l_{\alpha} t d \sigma_{\theta a k}, d q_{b k}=-2 \sin \frac{\phi}{2} l_{\alpha} t d \sigma_{\theta b k}
$$

半径方向の釣合条件より，以下の関係が成立する.

$$
d \boldsymbol{Q}_{a}+d \boldsymbol{Q}_{c}=\sum_{k=1}^{n_{q}} d q_{a k},-d \boldsymbol{Q}_{c}+d \boldsymbol{Q}_{b}=\sum_{k=1}^{n_{q}} d q_{b k}
$$

また, 材端回転角増分 $d \theta_{m a}, d \theta_{m b}$, およびヒンジ回転角増分 $d \theta_{a c}, d \theta_{b c}$ $d \theta_{c a}, d \theta_{c b}$ には以下の関係が成立する.

$$
\begin{aligned}
& l\left(d \theta_{m a}+d \theta_{a c}\right)=l\left(d \theta_{b c}-d \theta_{m b}\right)+d y \\
& d \theta_{m a}+d \theta_{a c}+d \theta_{b c}-d \theta_{m b}=d \theta_{c a}+d \theta_{c b}
\end{aligned}
$$

図7(a) と図 7(b)に示す材端力の増分には，以下の関係がある.

$$
\begin{aligned}
& d_{L} N_{\varphi m}=d N \\
& d_{L} Q_{\varphi m a}=d Q_{a}+d Q_{a R}, d_{L} Q_{\varphi m b}=d Q_{b}+d Q_{b R}
\end{aligned}
$$$$
d_{L} M_{\varphi m a}=-d M_{a}, d_{L} M_{\varphi m b}=d M_{b}
$$

ここで, $d Q_{a R}, d Q_{b R}$ は集中荷重 $d q_{a k}, d q_{b k}$ の反力として材端に作用 させる不釣合力増分であり，次式で表される。

$$
\begin{aligned}
& d Q_{a R}=\sum_{k=1}^{n_{q}}\left\{\frac{2 l-l_{\beta a k}}{2 l} d q_{a k}+\frac{l-l_{\beta b k}}{2 l} d q_{b k}\right\} \\
& d Q_{b R}=\sum_{k=1}^{n_{q}}\left\{\frac{l_{\beta a k}}{2 l} d q_{a k}+\frac{l+l_{\beta b k}}{2 l} d q_{b k}\right\}
\end{aligned}
$$

\subsection{5 軸方向変形}

座屈モデルの軸方向変形は, 4 つのヒンジの軸方向変形 $\left(u_{h a c}, u_{h c a}\right.$, $\left.u_{h c b}, u_{h b c}\right)$ ，および2つの直線材の軸方向歪による変形 $\left(u_{\varepsilon a}, u_{\varepsilon b}\right)$ と 回転による幾何学的な変形 $\left(u_{w a}, u_{w b}\right)$ である.

文献 21)より，図8に示す片持ち柱のヒンジの軸方向塑性変形增分 $d u_{h}$ は, 次式で与えられる。

$$
d u_{h}=\frac{4 l_{0} \sigma_{Y}}{\pi^{2} N_{y}}\left[\frac{2 n_{t}}{\sum_{i=1}^{n_{t}}\left(E_{i t 1}+E_{i t 2}\right)}-\frac{1}{E}\right] d N+\frac{\sum_{i=1}^{n_{t}} t_{i}\left(E_{i t 2}-E_{i t 1}\right)}{2 \sum_{i=1}^{n_{t}}\left(E_{i t 1}+E_{i t 2}\right)} d \theta
$$

一方, $d u_{w a}, d u_{w b}$ は, 次式で与えられる。

$$
\begin{aligned}
& d u_{w a}=l\left(\theta_{m a}+\theta_{a c}\right)\left(d \theta_{m a}+d \theta_{a c}\right) \\
& d u_{w b}=l\left(\theta_{b c}-\theta_{m b}\right)\left(d \theta_{b c}-d \theta_{m b}\right)
\end{aligned}
$$

図 9 に示す各分割領域 $l$ 間では歪度増分が一様であるから，直線材 の軸方向歪による変形増分 $d u_{\infty a}, d u_{\varepsilon b}$ は次式で与えられる.

$$
d u_{a a}=l_{\alpha} \sum_{k=1}^{n_{q}} d \varepsilon_{x a k}, d u_{c b}=l_{\alpha} \sum_{k=1}^{n_{q}} d \varepsilon_{x b k}
$$

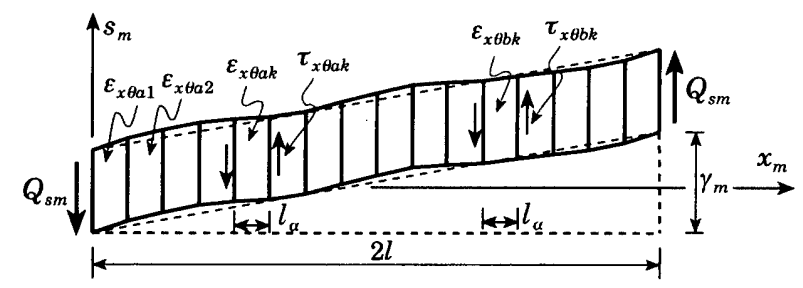

図 9 円周方向の剪断変形と剪断歪
軸方向歪度増分 $d \varepsilon_{x a k}, d \varepsilon_{x b k}$ は平面応力場の応力度一歪度関係より， 軸方向応力度増分, 円周方向歪度増分, およびせん断歪度増分を用い て表現可能となる。

\section{4 座屈域の材端力增分と材端変位增分関係}

上述の関係式を整理すれば,座屈モデルの部材座標系における材端 力増分 $\left\{d_{L} \boldsymbol{P}_{\varphi m}\right\}$ と材端変位增分 $\left\{d_{L} \boldsymbol{d}_{\varphi m}\right\}$ の間には，その剛性行列を $\left[{ }_{L} \boldsymbol{K}_{m}\right]$ として以下の関係を得る.

$$
\begin{aligned}
& \left\{d_{L} \boldsymbol{P}_{\varphi m}\right\}=\left[{ }_{L} \boldsymbol{K}_{m}\right]\left\{d_{L} \boldsymbol{d}_{\varphi m}\right\}
\end{aligned}
$$

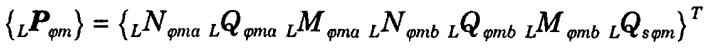

$$
\begin{aligned}
& \left\{{ }_{L} \boldsymbol{d}_{\varphi m}\right\}=\left\{{ }_{L} u_{\varphi m} \quad{ }_{L} \theta_{\varphi m a} \quad{ }_{L} \theta_{\varphi m b} \quad{ }_{L} \gamma_{\varphi m}\right\}^{T}
\end{aligned}
$$

図7(a)と図6(a)に示す座屈モデルの材端変位増分は，增分が十分小 さいものとして次式の関係で表される ${ }^{24)}$.

$$
\left\{d_{L} \boldsymbol{d}_{\varphi m}\right\}=[\boldsymbol{T}]\left\{d_{L} \boldsymbol{d}_{\varphi G}\right\}
$$

ここで, 行列 $[\boldsymbol{T}]$ は次式で表される.

$$
[\boldsymbol{T}]=\left[\begin{array}{ccccccc}
1-\frac{{ }_{L} v_{\varphi G a}-{ }_{L} v_{\varphi G b}}{2 l} & 0 & -1 & \frac{{ }_{L} v_{\varphi G a}-{ }_{L} v_{\varphi G b}}{2 l} & 0 & 0 \\
0 & \frac{1}{2 l} & 1 & 0 & -\frac{1}{2 l} & 0 & 0 \\
0 & \frac{1}{2 l} & 0 & 0 & -\frac{1}{2 l} & 1 & 0 \\
0 & 0 & 0 & 0 & 0 & 0 & 1
\end{array}\right]
$$

一方，材端力増分には以下の関係がある。

$\left\{d_{L} \boldsymbol{P}_{\varphi G}\right\}=[\boldsymbol{T}]^{T}\left\{d_{L} \boldsymbol{P}_{\varphi m}\right\}+[\boldsymbol{A}]\left\{d_{L} \boldsymbol{d}_{\varphi G}\right\}$

ここで, $[\boldsymbol{A}]$ は次式で表される.

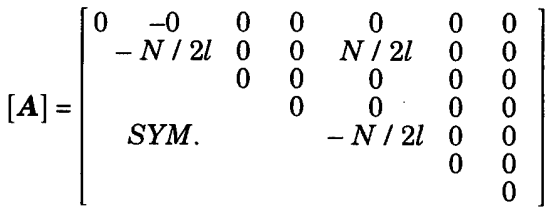

(26)式,(28)式より，全体座標系における材端力増分と材端変位増分 の関係が次式で得られる.

$$
\left.\left\{d_{L} \boldsymbol{P}_{\varphi G}\right\}=\left([\boldsymbol{T}]^{T}\left[{ }_{L} K_{m}\right]+[\boldsymbol{A}][\boldsymbol{T}]\right)\left\{d_{L} \boldsymbol{d}_{\varphi G}\right\}={ }_{L} \boldsymbol{K}_{\varphi G}\right]\left\{d_{L} \boldsymbol{d}_{\varphi G}\right\}(30)
$$
上式に(7)式の関係を用いれば，座屈域の材端力増分と材端変位増分 の関係が得られ，次式となる。

$$
\left.\left\{d{ }_{L} \boldsymbol{P}\right\}=\sum^{n_{d}}\left[{ }_{L} C\right]^{T}{ }_{{ }_{L}} \boldsymbol{K}_{\varphi G}\right]\left[{ }_{L} C\right]\left\{d{ }_{L} \boldsymbol{d}\right\}=\sum^{n_{d}}\left[{ }_{L} \boldsymbol{K}_{G}\right]\left\{d_{L} \boldsymbol{d}\right\}
$$

図1に示す曲げせん断棒には幾何学的非線形を考慮した弾性剛性を 与えれば，局部座屈を考慮した円形鋼管の剛性行列を得る。

\section{5 応力度一正度関係}

本解析で用いる応力度一歪度関係は, 文献 21)と同様に明瞭な降伏 点のない Ramberg-Osgood 型とし，次式で表現する.

$$
\begin{array}{lr}
\varepsilon=\varepsilon_{r}+\frac{\sigma-\sigma_{r}}{E} & \quad(32 \mathrm{a}) \\
\varepsilon=\varepsilon_{r}+\frac{\sigma-\sigma_{r}}{E}+0.002 x\left\{1.5\left(\frac{\left|\sigma-\sigma_{r}\right|}{x k \sigma_{Y}}-1\right)\right\}^{m} & (\text { (弾性域) } \\
\varepsilon=\varepsilon_{r}+\frac{\sigma-\sigma_{r}}{E}-0.002 x\left\{1.5\left(\frac{\left|\sigma-\sigma_{r}\right|}{x k \sigma_{Y}}-1\right)\right\}^{m} & (\text { 弾塑性域) }
\end{array}
$$

ここで, $\mathrm{E}=205 \times 10^{3}\left(\mathrm{~N} / \mathrm{mm}^{2}\right)$ とし, 降伏曲面の大きさを表すパラメー 夕 $k$ は処女載荷において 0.6 とする。したがって，処女載荷では $0.2 \%$ off-set 降伏応力度 $\sigma_{Y}$ を通り，その 6 割において弾性から弾塑性 に移行する応力度一歪度関係となる。 


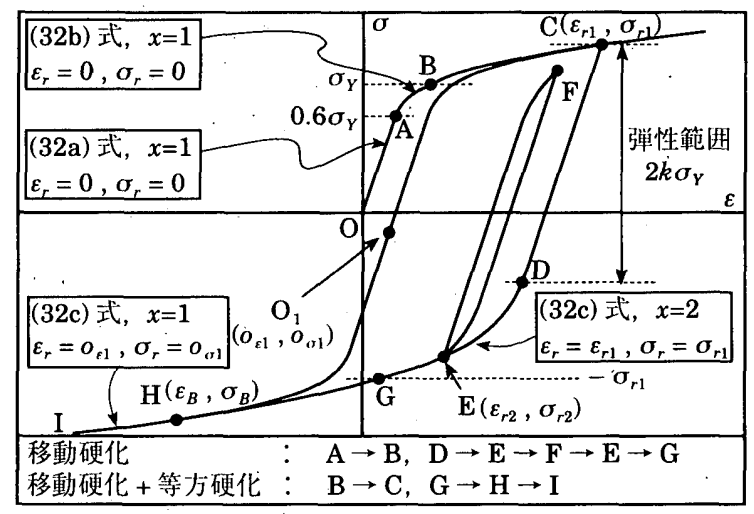

図 10 応力度一歪度関係履歴則

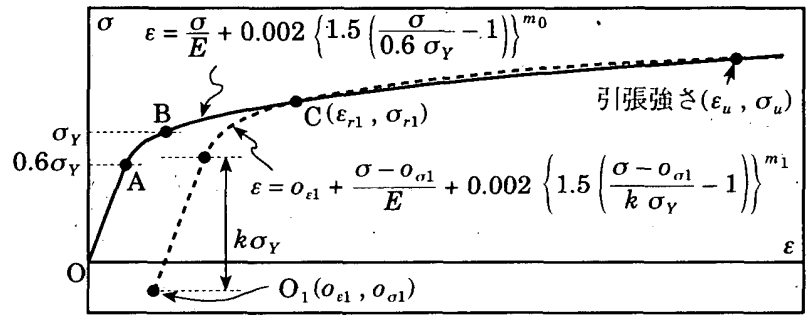

図 11 歪硬化を表す指数 $m$ の修正

表 1 試験体および素材試験結果

\begin{tabular}{|c|c|c|c|c|c|c|c|c|}
\hline $\begin{array}{l}\text { 試験 } \\
\text { 体名 }\end{array}$ & $\begin{array}{c}D \\
(\mathbf{m m})\end{array}$ & $\begin{array}{c}t \\
(\mathrm{~mm}\end{array}$ & $\frac{D}{t}$ & 軸力比 & $\begin{array}{l}\text { 載荷 } \\
\text { 方法 }\end{array}$ & $\begin{array}{c}\sigma_{y c} \\
(\mathrm{MPa})\end{array}$ & $\begin{array}{c}\sigma_{y t} \\
(\mathrm{MPa})\end{array}$ & $\begin{array}{c}\sigma_{u} \\
(\mathrm{MPa})\end{array}$ \\
\hline$\overline{D 17-1}$ & \multirow{3}{*}{216.3} & \multirow{3}{*}{12.7} & \multirow{3}{*}{17.1} & 0.3 & $\bar{M}$ & \multirow{3}{*}{345} & \multirow{3}{*}{362} & \multirow{3}{*}{403} \\
\hline D $17-2$ & & & & $0 . \overline{3}$ & $-\overline{\mathrm{I}}$ & & & \\
\hline D $17-3$ & & & & 0.6 & $\overline{\mathbf{I}}^{-1}$ & & & \\
\hline D28-1 & \multirow{4}{*}{216.3} & \multirow{4}{*}{7.90} & \multirow{4}{*}{27.8} & 0.3 & $\mathbf{M}$ & \multirow{4}{*}{351} & \multirow{4}{*}{402} & \multirow{4}{*}{439} \\
\hline $\mathrm{D} 28-2$ & & & & 0.0 & I & & & \\
\hline D28-3 & & & & 0.3 & $\overline{\mathbf{I}}$ & & & \\
\hline D28-4 & & & & 0.6 & $\bar{I}$ & & & \\
\hline D39-1 & 217.1 & 5.54 & 39.2 & 0.3 & $\mathrm{I}$ & 381 & 394 & 472 \\
\hline E27-1 & \multirow{5}{*}{\begin{tabular}{|l|l|}
114.3 \\
\end{tabular}} & \multirow{5}{*}{4.16} & \multirow{5}{*}{27.4} & 0.3 & M & \multirow{5}{*}{382} & \multirow{5}{*}{433} & \multirow{5}{*}{489} \\
\hline E27-2 & & & & 0.3 & $\mathrm{C}$ & & & \\
\hline E27-3 & & & & 0.3 & $\mathrm{C}$ & & & \\
\hline E27-4 & & & & 0.3 & $\overline{\mathrm{C}}$ & & & \\
\hline E27-5 & & & & 0.3 & $\mathrm{R}$ & & & \\
\hline E42-1 & \multirow{4}{*}{$\mid$\begin{tabular}{|l|}
$\mid 39.6$ \\
\end{tabular}} & \multirow{4}{*}{3.29} & \multirow{4}{*}{42.4} & 0.3 & $\mathbf{M}$ & \multirow{4}{*}{347} & \multirow{4}{*}{379} & \multirow{4}{*}{.442} \\
\hline E42-2 & & & & 変動 $(0.0)$ & M & & & \\
\hline E42-3 & & & & 0.3 & I & & & \\
\hline E42-4 & & & & 変動 $(0.3)$ & I & & & \\
\hline
\end{tabular}

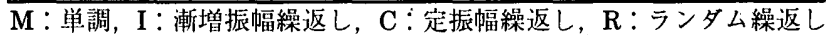
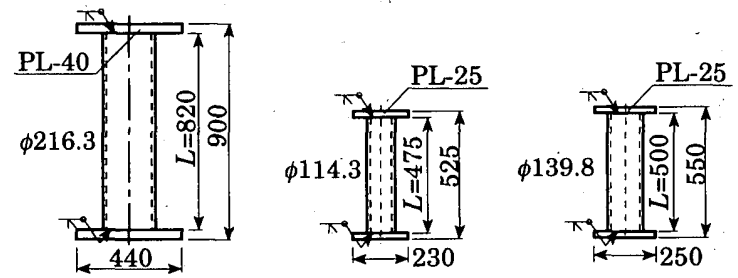

図 12 試験体
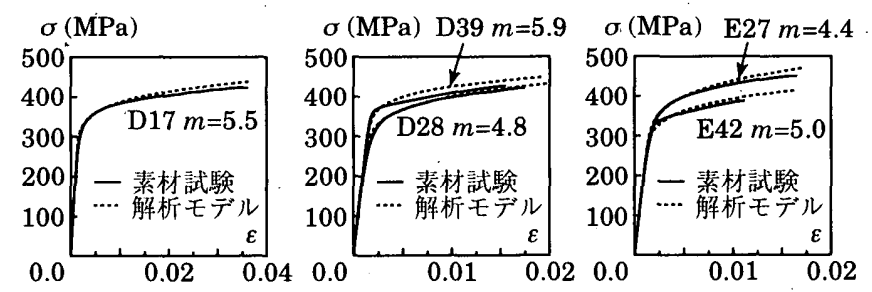

図 13 応力度一歪度関係
繰返しの履歴則は，中島，辻らが提案したI-K ROModel ${ }^{25)}$ を用い て移動硬化と等方硬化を考慮し，その関係を図 10 に示す．I-K RO Modelに従えば, 応力度一歪度関係の骨格部では $x=1, \varepsilon_{r}, \sigma_{r}$ は骨格 曲線の原点 $\left(O\right.$ または $\left.O_{1}\right)$ となり, 繰返し部では $x=2, \varepsilon_{r}, \sigma_{r}$ は最後 の除荷点 (C または $\mathrm{E})$ の歪度と応力度となる，等方硬化と移動硬化 が同時に生じる時, 全歪硬化に対する等方硬化の割合を $\beta$ とする。歪 硬化を表す指数 $m$ は, 短柱圧縮試験の結果を用いて求めるが, 等方硬 化を経験した後は図 11 に示すように骨格曲線が弓張強さに相当する 応力点 $\left(\varepsilon_{u}, \sigma_{u}\right)$ を通るよう, $m$ を修正する。

本論で用いる応力度一歪度関係は, 処女載荷の場合には文献 21)と 一致するが, 繰返しの履歴則は文献 21)とは異なる，文献 21)の歪硬 化は移動硬化のみであり,本論の歪硬化は等方硬化と移動硬化の組合 せである．本解析に文献 21)と同じ繰返し履歴則を用いると，単調載 荷の解析結果は実験結果のモーメントー回転角関係を良好に表現し得 るが, 繰返し載荷の解析結果は実験結果の耐力劣化を十分に表現する ことができず,実験結果の耐力劣化域において解析結果は耐力を過大 に評価する. 局部座屈の耐力劣化挙動は応力度一歪度関係に大きく影 響を受けるため, 本論では文献 21)とは異なる繰返しの履歴則を定義 して，耐力の過大評価に対する配慮を行った．すなうち，本論では歪 硬化に等方硬化と移動硬化の組合せを用い，等方硬化後に歪硬化勾配 が小さくなるような指数 $m$ の修正を導入した.ここで採用した履歴則 は, 実験結果と解析結果を比較しながら，試行錯誤によって決定した ものである。

\section{3. 円形鋼管の圧樎曲げ実験}

表 1 に試験体一覧を，図 12 に試験体形状を示す。試験体D17-1～3 はSTKN400，他はSTK400であり，いずれも材端にプレートを突合 わせ溶接している，表 1 に示寸 $\sigma_{y c}$ は短柱圧縮試験による圧縮降伏応 力度, $\sigma_{y t}, \sigma_{u}$ は素材引張試験. (JIS 14B 号試験片) による引張降伏応 力度と引張強さである。 D17，D28，D39は，それぞれ文献 21)の短 柱圧縮試験体 B-1, B-2, B-3 と同一ロットの鋼管である. 軸力比が変 動する試験体E42-4では，材端回転角が $0(\mathrm{rad}$.$) のとき軸力比を 0.0$ と し，材端回転角が 0.01 (rad.)増加する毎に軸力比を 0.1 増加させた。 ま た, 試験体 E42-4 では, 材端回転角が 0 (rad.)のとき軸力比を 0.3 導 入し，材端回転角が正側に $0.01(\mathrm{rad}$.)変化する.毎に軸力比を 0.1 増加 させ，負側に $0.01(\mathrm{rad}$.$) 変化する毎に軸力比を 0.1$ 減少させるよう載 荷した。

図 13 には，短柱圧縮試験によって得られた応力度一歪度関係と本 解析に用いる応力度一歪度関係 (解析モデル) を併せて示す. 実線は 短柱圧縮試験の結果, 点線は(32)式で定義した解析モデルである. $m$ は(32)式に必要な処女載荷時の歪硬化を与える指数である. 冷間成形 の円形鋼管には複雑な塑性加工に伴う異方性や残留応力が軸方向, 円 周方向あるいは板厚方向に存在する。しかし, 本解析に残留応力や異 方性を導入することは困難であり,解析対象の円形鋼管に存在する残 留応力ゃ異方性を的確に把握することも難しい.一方, 短柱圧縮試験 は管のまま載荷するため板厚方向や円周方向の降伏応力度の違いを平 均化して表すことができ,残留応力等の影響を含んだ応力度一歪度関 係を得ることができる.したがって, 本解析には残留応力や異方性を 直接導入しないが, 解析の応力度一歪度関係に短柱圧縮試験の結果を 用いることで，降伏応力度のばらつきと残留応力が考慮される。ま 
た, 本論では圧縮により生じる局部座屈が解析対象であることも，応 力度一歪度関係に短柱圧縮試験の結果を用いる理由の一つである.

図 14,15 に実験装置と載荷方法を示す. 外径が $216.3 \mathrm{~mm}$ の試験体 (Dシリーズ) は図 14 に示す試験装置で, 他 (Eシリーズ) は図 15 に 示す試験装置で実験を行った。載荷は所定の軸力を与え，試験体片側 に曲げモーメントを与える方法で行った。測定は軸力 $N$, 材端の曲げ モーメント $M$, 部材端回転角 $\theta$, および軸方向変形 $u$ である.

\section{4. 実験結果と解析結果の比較}

図 $16 \sim 18$ に曲げモーメントと回転角の関係を, 図 19 には回転角 と軸方向変形の関係を示す．図 16，19 では実線が実験結果，破線が 解析結果である.曲げモーメントは軸力比が一定の試験体では軸力を 考慮した全塑性モーメント $M_{p c}$ で無次元化し，変動軸力を受ける試験 体では軸力比 0.3 に対する $M_{p c}$ で無次元化している. 材端回転角 $\theta$ は, $M_{p c}$ に対する弾性回転角 $\theta_{p c}$ で無次元化している.

解析で与えた分割数は,弾塑性ヒンジにおける理想サンドイッチ断 面の組数 $n_{t}$ を 3 , 弾塑性直線材の分割数 $n_{q}$ は 5 とした. 円形鋼管断面 の分割数 $n_{d}$ は, 単調載荷の解析では 8 , 繰返し載荷の場合は精度を確 保するため 12 と大きくしている．また，応力度一歪度関係における 全歪硬化に対する等方硬化の割合 し，局部座屈の半波長 $l$ は文献 21)と同様に，次式で与えた.

$l / t=1.25 \sqrt{\dot{D} / t-1}$

図 16,19に示す単調載荷の解析結果と実験結果を, 図 20 に示す指 標を用いて比較し, その結果を表2示す. 指標は最大耐力 $M_{\max }, M_{\max }$ の95\%まで耐力劣化した点における塑性変形倍率 $\eta_{95}, M_{\text {max }}$ から $M_{\text {max }}$ の 80\%（D17-1では 95\%）になる点までの平均耐力劣化勾 $k_{80}^{-}, M_{p c}$ （D17-1では $M_{\max }$ の 95\%）まで耐力劣化した点での塑性吸収エネル ギー $E_{p}$, および $M_{\max }$ 時の軸方向変形 $u_{\max }$ である. 表 2 に示す各指標 の右下添字 $c$ は解析結果を, $e$ は実験結果を表す．表 2 に示す最大耐 力比はいずれも 1.0 に近く, 実験結果と解析結果の差は $5 \%$ 以下, $\eta_{95}$ ではD17-1を除けば $10 \%$ 以下である. $k_{80}^{-}$の実験結果と解析結果の差 は $M_{\max }$ や $\eta_{95}$ に比べて大きく，D28-1，E27-1，E42-1では解析結果 の耐力劣化勾配は実験結果に比べて小さい。これは，座屈域を直線材

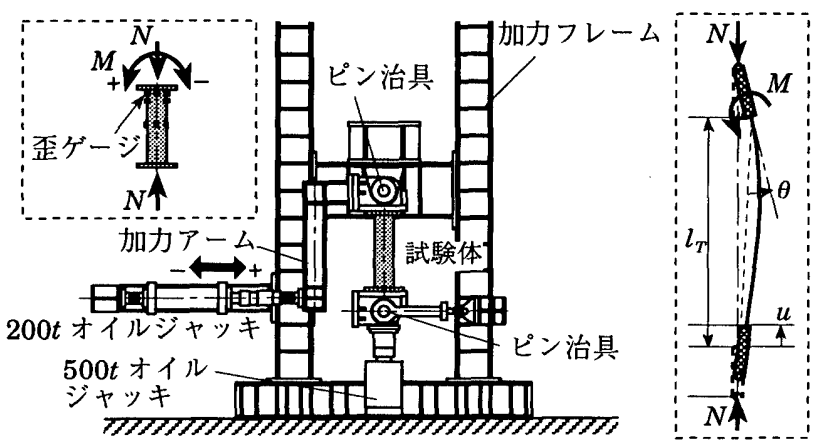

図 14 実験装置および載荷方法（Dシリーズ）

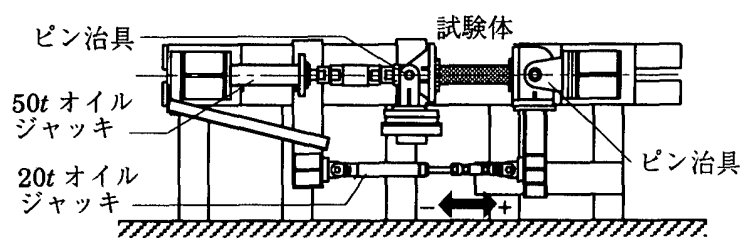

図 15 実験装置および載荷方法（Eシリーズ）
でモデル化したことにより実際より最大たわみが大きくなり，座屈拘 束となる円周方向の応力が過大に評価されたため21)と考えられる。一 方，D17-1の実験結果の耐力劣化勾配が解析結果より小さい原因は， 座屈域以外が塑性変形したためと考えられ，E42-2は変動軸力を受け るためE42-1とは異なる傾向が生じたと考えられる.最大耐力時の軸 方向変形 $u_{\text {max }}$ にはやや大きな差が認められるが, 軸方向変形を図 19 に示すように回転角と比較すれば実験結果と解析結果は良く対応して いると言える.D17-1の実験結果は解析結果よりも軸方向変形が大き いが,これは座屈域以外に塑性変形が生じたことを示唆している. 吸 収エネルギーの指標 $E_{p}$ は D17-1を除けば実験結果と解析結果の差は 10\%以下であり,本解析は耐力上昇から最大耐力を経て局部座屈によ る耐力少化までの挙動を良好に表現し得ると考えられる。

繰返し載荷の実験結果と解析結果の比較は, 最大耐力 $M_{\text {max }}$, 除荷 時耐力 $M_{R}$, 半サイクルの塑性吸収エネルギー $E_{p}$, および除荷時軸方 向変形 $u_{R}$ を指標として用い, 図 21 に比較指標の定義と比較結果を示 す. 比較指標の右下添字 $c$ は解析結果, $e$ は実験結果である. $M_{\max }$ の 実験結果と解析結果の差は単調載荷よりも大きく, D17-3 と D28-4を 除けば最大で約 $15 \%$ 程度である. $M_{R}$ の実験結果と解析結果の美は $M_{\max }$ と同様な傾向を示し, 繰返しサイクルが増す毎に大きくなる.単 調載荷に比べて繰返し載荷の場合に差が大きくなる原因は, 繰返しの 応力度一歪度関係が必ずしもRamberg-Osgood型で十分に表現し得な いためと考えられる.一方， $E_{p}$ は変位振幅の小さいサイクルにおいて 差が大きいが, 局部座屈による劣化挙動が生じる振幅の大きいサイク ルでは実験結果と解析結果の差は $10 \%$ 程度で, 単調載荷の場合と同程 度となる。また，除荷時の軸方向变形 $u_{R}$ もイクルが増すと実験結 果と解析結果の差は $10 \%$ 程度と小さくなり，良く对応している.

比較指標を用いた上記の評価では, 実験結果と解析結果は完全には 一致しないが, 解析結果は異なる径厚比や軸力比, あるいは繰返し方 法に対し，耐力上昇や耐力劣化を良好に表現しており，円形銅管の局 部座屈挙動を評価するに十分な精度を有していると言えよう。

図 22 には単調載荷による基準化径厚比 $\left(D / t \cdot \sigma_{y} / E\right)$ と最大曲げ耐 力 $\left(M_{\text {max }} / M_{p c}\right)$ の関係を, 図23には基準化径厚比と変形能力（最大 曲げ耐力時の塑性変形倍率)の関係をそれぞれ既往の研究結果とあわ せて示す. 図中の実線は本解析によって求めた予測值であり，軸力比 が0.0，0.3，0.6の3 種類について示している。この予測に必要な降 伏応力度と引張強さは, 越智らの提案した統計量27)を用いた。破線は 既往の研究において提案された予測值 ${ }^{28 \sim 30)}$ ，プロットは本論と既往 の実験結果 29,31)であり，軸力比の範囲を 2 種類に分けて示している. 既往の実験結果は円形鋼管に曲げ勾配があるものを対象としたが, 短 柱圧縮試験が行われていないものもあるため, 図 22,23 の $\sigma_{y}, M_{p c}$ は引張降伏応力度を用いて整理している. 図中の $\mathbf{A}$ と示された領域の
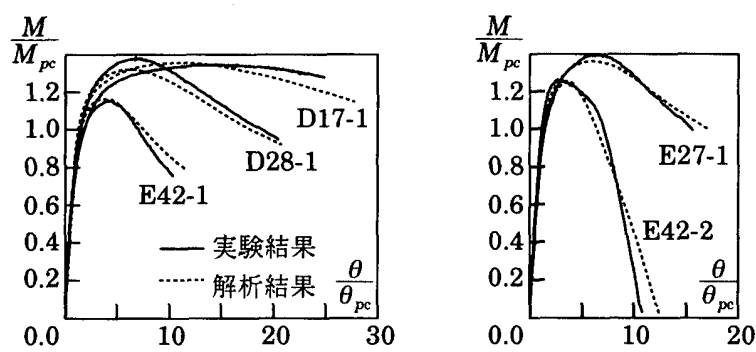

図 16 曲げモーメントー回転角関係（単調載荷） 

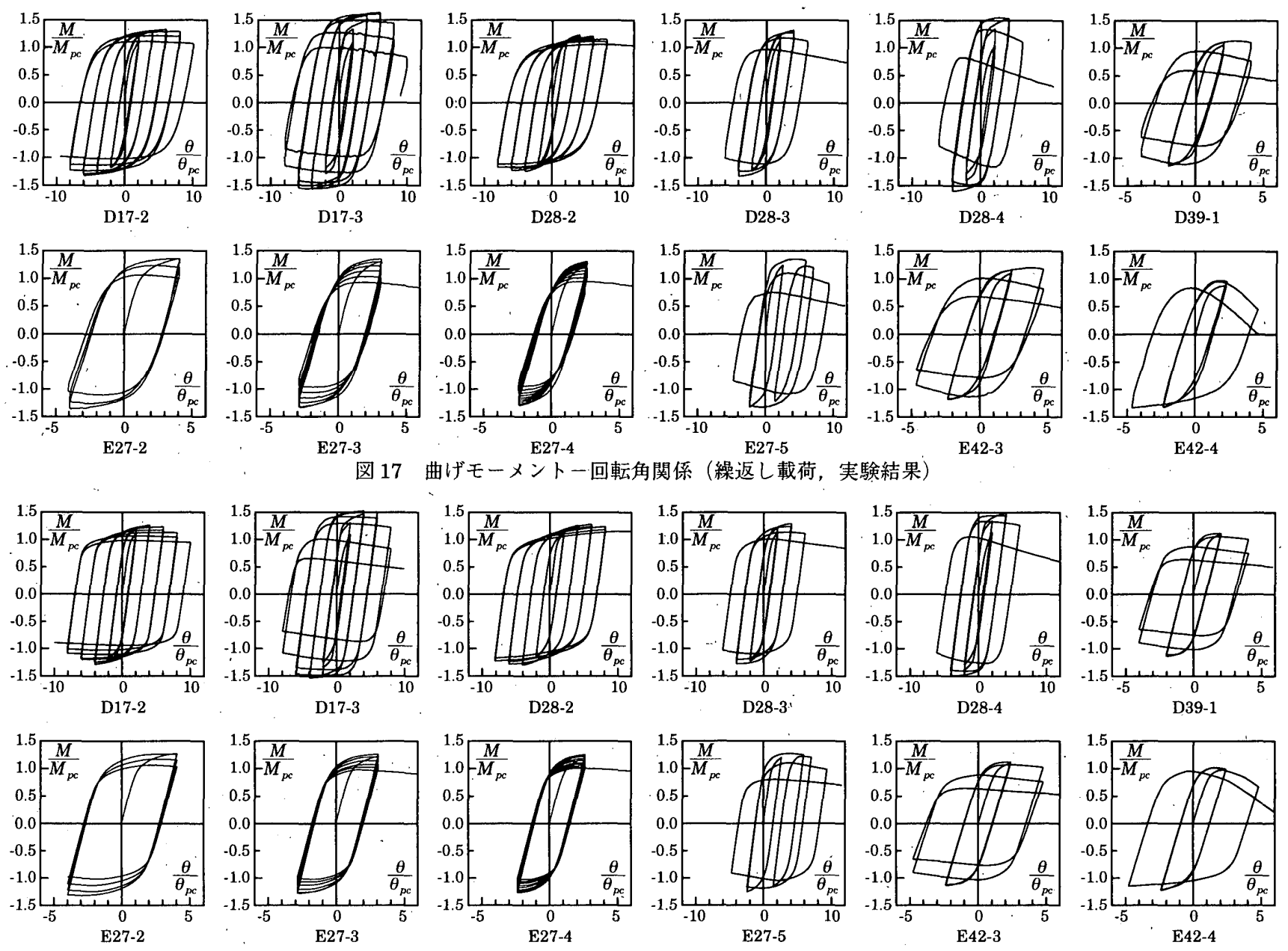

図 18 曲げモーメントー回転角関係（繰返し載荷, 解析結果)
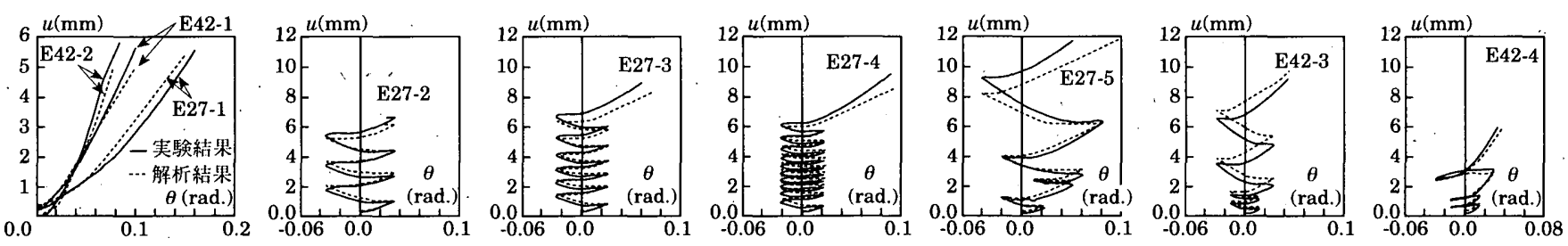

図 19 回転角一軸方向変形関係

表 2 実験結果と解析結果の比較

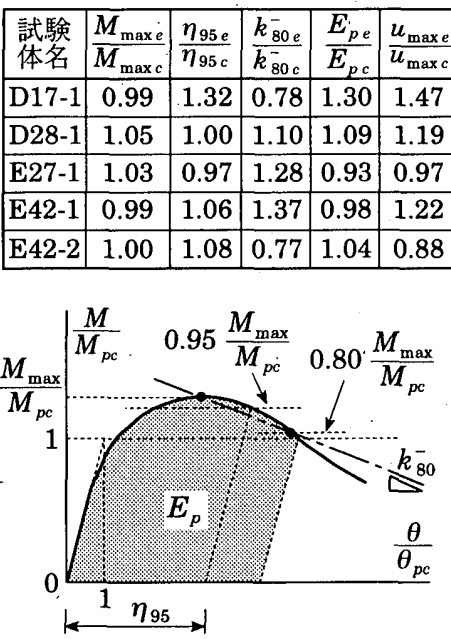

図 20 単調載荷の比較指標
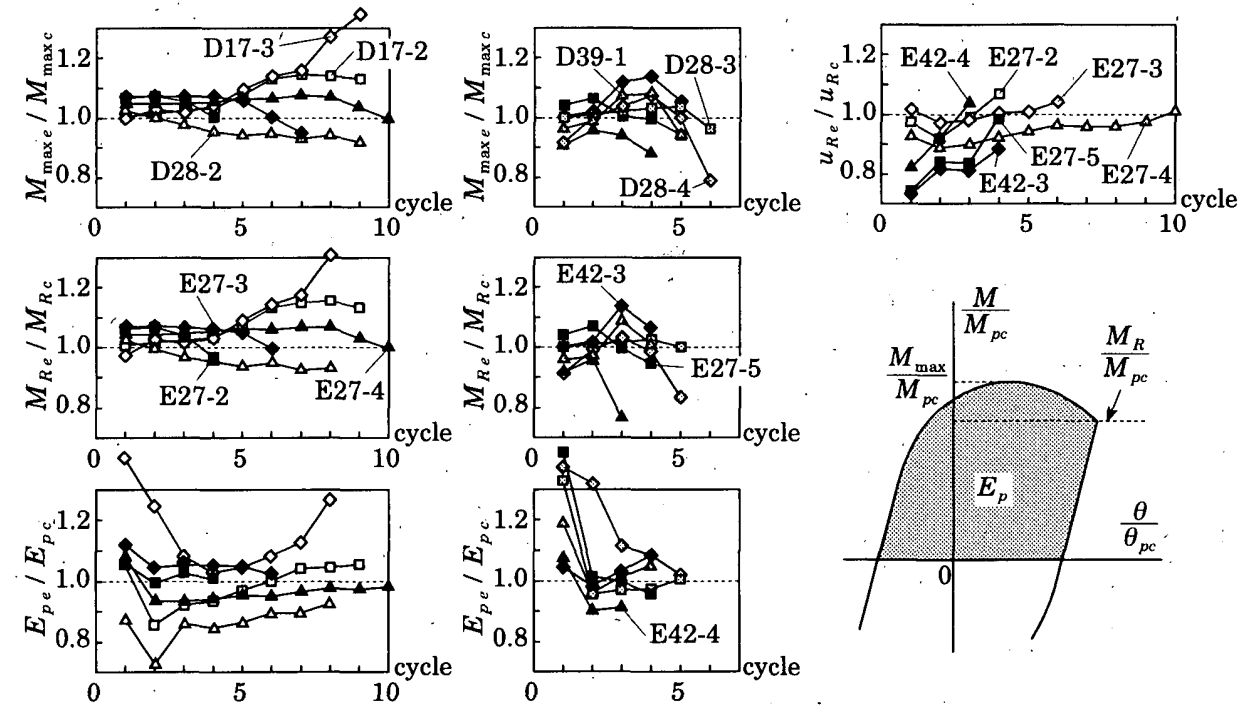

図 21 実験結果と解析結果の比較（繰返し載荷） 

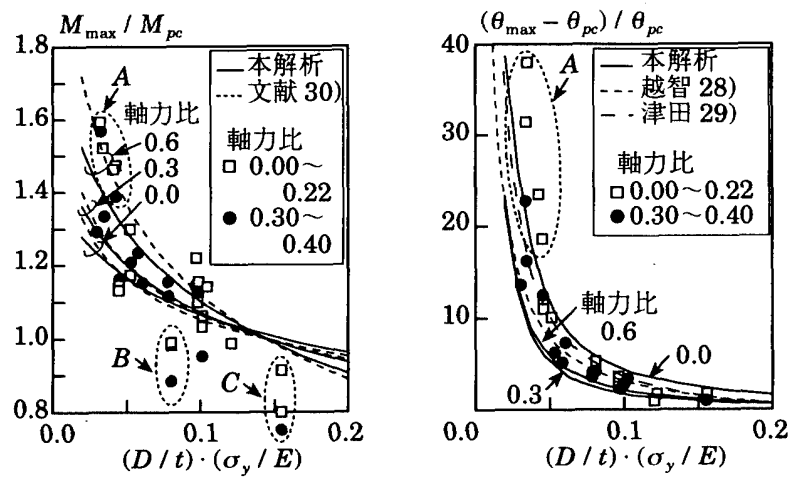

因 22 径厚比と最大耐力の関係 図 23 径厚比と変形能力の関係

実験結果は熱間圧延材であり，他は冷間成形材である. 熱間圧延材は 最大酎力, 変形能力とも大きな值を示している.

図 22 に示す実験結果にはばらつきがあり，明瞭な軸力比による差 は見られない. 図中の $B, C$ と示された領域の実験結果を除けば，本 解析による予測值は実験結果と概ね対応している. 領域 $B$ の試験体の 最大耐力が予測值より低い原因は, 降伏応力度と降伏比が解析で仮定 した值(365MPa，79\%)に比べて高い值(415MPa，89\%)であったた めと考えられる.また，領域 $C$ の試験体も降伏比が統計量に比べて高 いため，予測値より最大耐力が低くなったと考えられる．図 22 に示 す本解析の予測值は降伏応力度と引張強さに統計量を用いたため実験 結果と必ずしも対応はしないが, 文献30)の最大耐力予測式にも同じ 統計量を用いれば（図 22 の破線），本解析の予測值と良く対応する。

図 23 に示す本解析の予測值は，軸力比 0 の場合に変形能力を大き く評価するが, 軸力比 0.3 と 0.6 の場合ではほとんど違いはなく, 軸 力比 0.3 の予測値は実験結果や既往の提案式の下限值となっている.

\section{5. 結}

本論では, 変動軸力と繰返し曲げを受ける円形鋼管が, 局部座屈を 生じて耐力劣化する挙動を追跡するための解析方法を提案した。解析 モデルは弾塑性ヒンジにより崩壊機構を仮定するモデルであり, 円形 鋼管の寸法と素材の応力度一歪度関係のみ与えれば解析が可能であ る. 本論で提案した解析方法を検証するため, 軸力と曲げを受ける円 形鍓管の実験結果と解析結果を比較した. その結果, 異なる径厚比や 軸力比, 繰返し方法に対し, 解析結果は実験結果の耐力上昇や耐力劣 化を良好に表現し,本論で示した解析方法が円形鋼管の局部座屈挙動 を評価するに十分な精度を有していることを明らかにした。

本論で提案した解析モデルを用いれば,耐力劣化の復元力特性を与 えることなく,任意の円形鋼管に村して局部座屈挙動を含む地震時の 骨組挙動を追跡することが可能となる.

\section{謝辞}

本実験に際しては, 大阪大学大学院工学研究科建築工学専攻 多田 元英助教授，同 桑原進講師，同 松井貴志技官には多大な御援助， 御協力を頂いた. 付記して感謝の意を表する.また, 本研究は平成 12 年度の（社）鋼材俱楽部「建築鋼横道助成金利度」による援助を受け た. 末筆ながら感謝の意を表する。

\section{参考文献}

1) 三谷勲, 牧野秢, 松井千秋：H形鋼柱の局部座屈後の変形性状に関する解 析的研究 (その1) 単調載荷を受ける場合, 日本建築学会論文報告集, 第
296 号, pp.37-47, 1980.10

2）三谷勲，牧野稔，松井千秋：H 形鋼柱の局部座屈後の変形性状に関する解 析的研究 (その2) 繰返し載荷を受ける場合, 日本建築学会論文報告集, 第 301 号, pp.77-86, 1981.3

3）菘井千秋，吉住孝志：鉄骨ラーメンの弾塑性変形性状に及ほす局部座屈の 影響，日本建築学会論文報告集，第 845 号, pp.50-60, 1984.11

4）孟令葆，大井謙一，高梨晃一：鉄骨骨組地震応答解析のための耐力少化を 伴う簢易部材モデル，日本建築学会構造系論文報告集, 第 437 号, pp.116$124,1992.7$

5) 大井謙一, 陳以一, 高梨晃一：変動軸力と水平荷重を受ける $\mathrm{H}$ 形鋼柱の弾 塑性挙動に関する研究，棈造工学論文集, Vol. 38B, 1992

6) 陳以一, 大井謙一，高梨晃一:3方向变動荷重を受ける箱型断面鋼柱の弾塑 性挙動，日本建築学会構造系論文報告集，第 447 号, pp.139-148, 1993.5

7) Uchda, Y. and Morino, S. :Limit of Axial Force Ratio for Degrading Steel Beam-Columns Involving Local Buckling, 日本建筑学会構造系論文報告 集，第 425 号，pp.67-68，1991.7

8) 内田保博：軸力及び繰返し曲げを受け耐力低下を生じる柱の変形累積の安 定性，日本建築学会構造系諭文報告集，第 448 号, pp.134-140，1993.6

9) 内田保博, 三谷勲, 上達野明夫 : 角形鋼管柱の軸力比制限に関する実験的 研究，日本建築学会構造系論文報告集，第 448 号, pp.139-149，1998.12

10) 内田保博, 古里角栄：局部座屈を生じる角形鋼管柱の累積績賃予测に関す る研究，日本建築学会構造系論文集，第 531 号, pp.141-148, 2000.5

11）山田哲，秋山厷，桑村仁：局部座屈を伴う箱形断面部材の少化域を含む終 局挙軌日本建築学会構造系論文報告集, 第 444 号, pp.135-143, 1993.2

12）山田哲，秋山宏，桑村仁：局部座屈を伴う $\mathrm{H}$ 形断面部材の少化挙動, 日本 建築学会構造系論文報告集，第 454 号, pp.179-186, 1998.12

13）山田哲,秋山宏：局部座屈を伴う鋼部材の挙動に立脚した多層骨組の弾塑 性応答解析，日本建築学会棈造系論文集，第 463 号, pp.125-133, 1994.9

14）清水孝憲，金谷弘，上場輝康，田中風，脇田孝彦：円形鋼管の曲げ压縮挙 動の数值解析, 日本建築学会近畿支部研究報告集, pp.161-164, 1994.6

15）来田光正，上場輝康，脇田孝彦：軸力と曲げを受ける径厚比の小さい円形 銅管柱に関する研究，日本建築学会近畿支部研究報告集, pp.237-240,1996

16）小野徹郎，石田和人，吉田文久：軸圧縮を受ける箱形断面短柱の局部座属 領域に関する垁験的研究, 日本建築学会構造系論文集, 第 493 号, pp.107$114,1997.8$

17) 和田章, 広瀬景一: 2 万向地震動を受ける無均等ラーメン構造の弾塑性応答 性状，日本建築学会構造系論文報告集，第 399 号, pp.37-47, 1989.5

18）加藤勉. 秋山弘：地震時におけるせん断型骨組の倒壊条件, 日本建築学会 論文報告集，第 244 号, pp.33-39, 1976.6

19）小川厚治，黑羽啓明，待鳥腎治，馬淵信一郎：劣化域を考慮した鋼構造物 のエネルギー吸収能力の評価基準に関する一考察, 日本建築学会構造系論 文集，第 492 号，pp.113-119，1997.2

20) 桑村二，伊山潤，朱大立：局部座屈少化系の地震による倒壊および残留変 形，日本建築学会楧造系論文集，第 526 号, pp.169-176, 1999.12

21) 安井信行:綝返し軸力を受ける円形鋼管の局部座屈挙動解析に関する研究， 日本建築学会構造系論文集, 第 543 号, pp.161-168, 2001.5

22) F. R. Shanley:Inelastic Column Theory, Journal Aeronautical Science, 14, No.5, pp.216-268, 1947

23）山田嘉昭：塑性・粘弾性, 培風館, 1980

24) Alan Jennings : Frame Analysis Including Change of Geometry, Journal of the Structural Division, Proc. ASCE, No.ST3, pp.627-644, March, 1968

25) Masayoshi Nakashima, Takashi Akazawa, Bunzo Tsuji : Strain-Hardening Behavior of Shear Panels Made of Low-Yield Steel, II:Model, Journal of Structural Engineering, pp.1750-1757,December,1995

26) Z. Mrôz : Hardening and Degradation Rules For Metals Under Monotonic and Cyclic Loading, Journal of Engineering Materials and Technology Vol. 105, pp.113-118, April, 1983

27）越智健之, 黒羽啓明: 冷間成形円形鋼管部材の耐力と变形能の統計的評価 日本建築学会構造系論文報告集, 第 391 号, pp.59-70, 1988.9

28）越智健之, 最相元雄，黑羽啓明：冷間成形円形鋼管部材の变形能力, 日本 建筑学会大会学術䛾演梗概集, pp.1119-1120, 1986.8

29）津田惠吾，松井千秋：一定軸力と変動水平力を受ける円形鐥管柱の弾塑性 性状, 日本建築学会構造系論文集, 第 505 号, pp.131-138, 1998.3

30）（社）鋼材俱楽部：中低層鉄骨建物の酎震設計法, pp.177-182，1978

31) 越智健之, 最相元雄, 黑羽答明, 大塚孝志 : 円形鍓管部材の履歴性状 (そ の1. 耐力, 変形能と径厚比), 日本建築学会大会学術講演梗柣集, pp.667$668,1985.10$ 